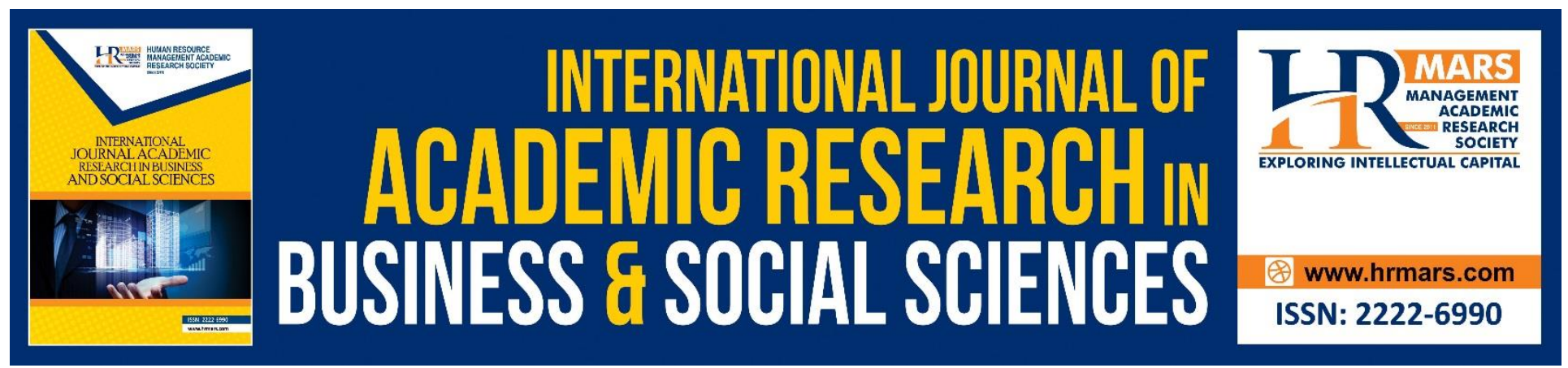

\title{
The Motives and Selection Criteria of Korean Firms in Establishing Inter-Firm Network with Suppliers in Malaysia
}

\section{Wonik Kim, Raja Nerina Raja Yusof}

To Link this Article: http://dx.doi.org/10.6007/IJARBSS/v10-i10/7702

DOI:10.6007/IJARBSS/v10-i10/7702

Received: 29 August 2020, Revised: 22 September 2020, Accepted: 17 September 2020

Published Online: 20 October 2020

In-Text Citation: (Kim, \& Yusof, 2020)

To Cite this Article: Kim, W., \& Yusof, R. N. R. (2020). The Motives and Selection Criteria of Korean Firms in Establishing Inter-Firm Network with Suppliers in Malaysia. International Journal of Academic Research in Business and Social Sciences. 10(10), 842-858.

\section{Copyright: (c) 2020 The Author(s)}

Published by Human Resource Management Academic Research Society (www.hrmars.com)

This article is published under the Creative Commons Attribution (CC BY 4.0) license. Anyone may reproduce, distribute, translate and create derivative works of this article (for both commercial and non-commercial purposes), subject to full attribution to the original publication and authors. The full terms of this license may be seen at: http://creativecommons.org/licences/by/4.0/legalcode

Vol. 10, No. 10, 2020, Pg. 842 - 858

Full Terms \& Conditions of access and use can be found at http://hrmars.com/index.php/pages/detail/publication-ethics 


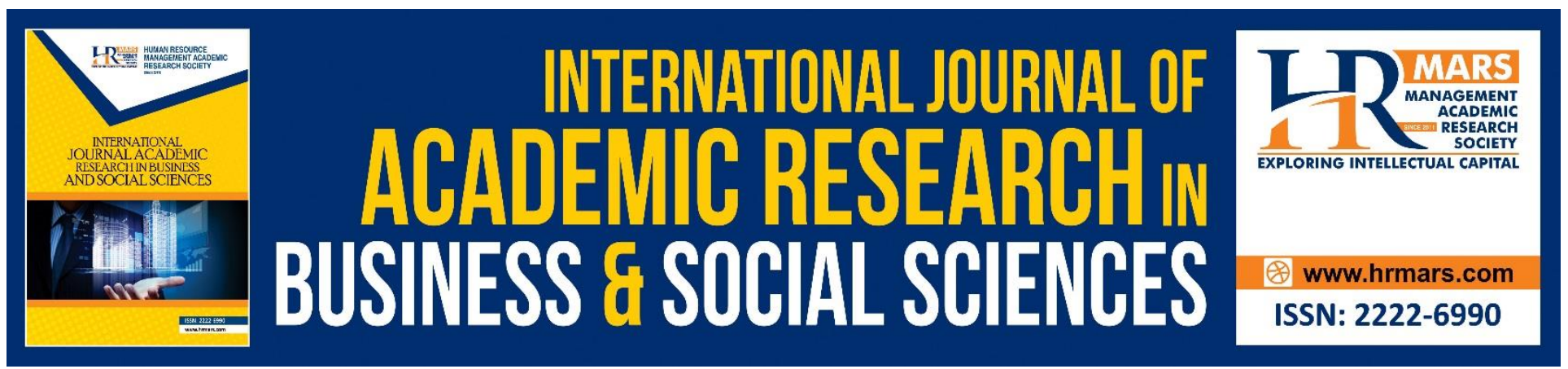

\title{
The Motives and Selection Criteria of Korean Firms in Establishing Inter-Firm Network with Suppliers in Malaysia
}

\author{
${ }^{1}$ Wonik Kim, ${ }^{2}$ Raja Nerina Raja Yusof \\ ${ }^{1}$ Putra Business School, Universiti Putra Malaysia, ${ }^{2}$ Faculty of Economics and Management, \\ Universiti Putra Malaysia \\ Email: Kimwi99@gmail.com,nerina@upm.edu.my
}

\begin{abstract}
This research, which focuses on Korean firms, aims to explore the intricacies of the network relationships between buyers and suppliers. Since the influence and strategies of the inter-firm network of overseas Korean firms have not been satisfactorily explored yet, this study attempts to fill the gap by exploring the motives and selection criteria of these firms. The findings revealed that there were three main motives for Korean firms to establish inter-firm networks with suppliers in Malaysia, which are locational decisions, low-cost sourcing, and easiness for procurement. Findings also showed that Korean firms select their suppliers based on seven criteria which are business structure, production capability, partner experience, quality policy, price competitiveness, business potential and relationship. The study suggested practical recommendations for potential suppliers of Korean firms in developing supplier-buyer relationships.
\end{abstract}

Keywords: Inter-Firm Network, Korean Firms, Motives, Selection Criteria, Supplier, Case Study.

\section{Introduction}

The importance of networks has emerged as one of the domain frameworks to explain the global phenomenon of internationalisation across most industrial sectors (Johanson \& Kao, 2010). Companies seeking to enter foreign markets make important strategic decisions about how to use networks in a specific market (Lu, 2002). Although the inter-firm network may differ for every industrial sector due to differences in their reaction to transaction cost based variables and risks, when firms conduct business in foreign markets, they use a variety of networks, such as finance, supply, transportation, content, service, and social (Walker \& Hampson, 2003). These different types of networks are important in the early stage of international expansion for strategic decision concerning control, risk, and supply chain.

Dicken (1998) has defined inter-firm networks as something taking place 'between firms belonging to separate but overlapping business networks as part of customer-supplier relationships'. Besides, inter-firm network is also defined as voluntary agreements between companies relating to the 
INTERNATIONAL JOURNAL OF ACADEMIC RESEARCH IN BUSINESS AND SOCIAL SCIENCES Vol. 10, No. 10, 2020, E-ISSN: 2222-6990 @ 2020 HRMARS

exchange, sharing or joint development of products, technologies or services (Gulati, 1998; Zheng, et al., 2010). Thus, inter-firm network is composed of sets of independent parties, which cooperate for mutual benefits with shared information and frequent interactions.

Previous studies on inter-firm network mostly focused on the factors that lead to the success of firms in localizing their operations in foreign host countries in terms of firm-specific factors (Li \& Cheong, 2017), policy-related factors (Crone \& Watts, 2003; Krätke \& Borst, 2007) and social-related factors (Rooks, Raub, Selten \& Tazelaar (2000). There are also studies examining the impact of inter-firm networks on multinational firms' internationalization (Li \& Yeung, 1999; Yang, Wang \& Jiang, 2019; Su, Khan, Lew, Park \& Choksy, 2020). Though factors and impact of inter-firm networks are important, the fact that inter-firm network takes significant effort and time to establish, it is quite surprising that not many research can be found looking into the process of establishing the inter-firm network itself.

The process of forming a network relationship in business and the resulting structure of inter-firm network has likely played an important role in shaping the Korean firms' business structure. After making a great effort to establish inter-firm network, it was found that $29.5 \%$ of the Korean firms increased their sales (Yozi, 1997). Generalising the results of a certain industry to every industry may be difficult, however, relatively speaking, inter-firm network did help Korean firms to increase communication and sales (Lee, 2004).

However, many existing research on inter-firm network of Korean firms is focused on the business network within Korea only (Park \& Nahm, 1998; Kwon, 2010; Son, Han \& Rojas, 2015). Network practices that can be reproduced outside of Korea have not been explicitly studied (Lopez-Aymes \& Salas-Porras, 2008). As Korean firms become more internationalised and have struggled to invest overseas, they established production networks and acquired local companies in certain countries to expand their business. Nevertheless, little research is done on the business network of Korean firms' subsidiaries and locally founded Korean firms as well as the relationship between both business parties (Gress, 2007).

Hence, this study focused on the process of establishing inter-firm networks of Korean firms in the Malaysian market. Specifically, the study is interested to explore the motives underlying the Korean firms in establishing inter-firm networks (i.e. suppliers), and their selection criteria in choosing the firms as their suppliers in Malaysia. The study examined how network theory contributed to the international expansion of Korean firms in the Malaysian market.

\section{Literature Review}

\section{Motives of Inter-Firm Network}

Many researchers have found the transaction cost theory and resource-based view useful in explaining the reasons for making certain decisions and processes concerning the inter-firm network (Lavie, 2006). When using the transaction cost approach to investigate inter-firm networks, the level of analysis is the contractual defined level. In other words, it is a motivational inter-firm network between two different firms established for economic purposes that is motivated and measured before, during, and after formal contracts or agreement with costs and obligations (Gress, 2007; 
INTERNATIONAL JOURNAL OF ACADEMIC RESEARCH IN BUSINESS AND SOCIAL SCIENCES Vol. 10, No. 10, 2020, E-ISSN: 2222-6990 @ 2020 HRMARS

Johanson \& Mattsson, 1987). In this context, transaction cost theory tends to emphasise on the 'type' of exchange, rather than the 'nature' of the exchange (Dicken \& Thrift, 1992; Gress, 2007).

On the other hand, the resource-based view mainly focuses on the internal corporate source of sustainable competitive advantage. The resource-based view argues that companies with valuable, rare, imperfectly imitable, and non-substitutable resources can secure and maintain a competitive advantage (Barney, 2001). A firm's ability to control and create critical competencies is the most important foundation of competition, hence, firms must have sufficient access and control of valuable resources, both internally and externally. Furthermore, the resource-based view shows that cooperation between businesses provides an opportunity to get resources to businesses that lack the resources (Chin et al., 2008). Thus, some studies on the resource-based view and inter-firm network have used the term 'network resources', which is defined as the resources owned by incorporated firms, which can be accessed by the focal firm through its network ties with those firms (Gulati, 2007). In contrast to the resource-based view, transaction cost theory emphasises that firms can source via internal or external activities, depending on the relative transaction costs implication to minimise cost. However, two different types of theories and perspectives are insufficient to explain inter-firm network because these two do not sufficiently show the strategic practices for the network (Kraaijenbrink, et al., 2010).

Thus, the resource-based view and transaction cost theory share a commonplace criticism in the debate that the environment has been neglected or not treated in detail. For example, the transaction cost theory is restricted to the transaction cost-minimising rationales, but the decision on export intermediary selection may be constrained for other reasons under different institutional contexts. Similarly, a few studies that had used resource-based view examined strategy differences in the social context in which resource choice decisions such as corporate tradition and network relations were embedded. Moreover, although some capabilities are standard across all economies, others are more prominent in emerging economies (Hoskisson et al., 2000). Therefore, it is vital for foreign exporting firms to calculate the institutional contexts of export-related costs and capabilities (Ma, 2006).

\section{Selection Criteria of Inter-firm Network}

Inter-firm network selection involves identifying the potential of network partners to create valueadding potentials (Moeller, 2010). Selection of partners has been emphasised as one of the core tasks to form a strong network among partners. Previous research on networks has suggested a generic model that assumes the factors that drive the attractiveness of a partner and drive the likelihood of choice and is consistently applied to various alliance projects and situations (Shah \& Swaminathan, 2008). Most studies on the selection of partners have shown that among the factors which affect partner selection and its performance are trust, commitment, and complementarity.

In addition, many scholars have mentioned that trust among partners is a key factor in minimising network uncertainty (Das \& Teng, 2000; Gulati, 1995). Trust in the business network allows partners to participate appropriately in the business network by streamlining the decision-making process and reducing uncertainties (Bass, Klein \& Bachmann, 2003). As such, trust is one of the main determinants 
INTERNATIONAL JOURNAL OF ACADEMIC RESEARCH IN BUSINESS AND SOCIAL SCIENCES Vol. 10, No. 10, 2020, E-ISSN: 2222-6990 @ 2020 HRMARS

of relationships that are determined via partner selection within the business network (Moeller, 2010).

Firms are likely to continue to maintain their current partner relationships to alleviate the concern of selecting potential partners. Recommended partnership is a process that the company has formed as an introduction of non-consolidated firms to the current network partners. Therefore, the network selection process is one of the criteria vital for network success. Companies may have many or their own steps in their partner selection process. Theoretically, in general, the partner selection process involves five formalised steps (Table 1).

Table 1: Partner selection process

\begin{tabular}{|c|c|c|}
\hline Step & Main activity & Description \\
\hline 1 & Searching for partners & $\begin{array}{l}\text { - Searching and evaluating potential business } \\
\text { partners based on economic or social } \\
\text { perspectives. } \\
\text { - } \text { No active commitment by each party. }\end{array}$ \\
\hline 2 & $\begin{array}{l}\text { Developing } \\
\text { relationship }\end{array}$ & $\begin{array}{l}\text { - Testing and identifying common goals and } \\
\text { compatibility with potential network partners. } \\
\text { - Selecting entry based on abilities and short- or } \\
\text { long-term compatibilities of partners. }\end{array}$ \\
\hline 3 & Initiating relationship & $\begin{array}{l}\text { - Planning of activities, responsibilities, and } \\
\text { relationships. } \\
\text { - Evaluation of the relationship process for } \\
\text { identification of mutual obligation of performance } \\
\text { and effectiveness. } \\
\text { - Creating synergistic value and strengthening } \\
\text { interdependent commitment with mutual benefits } \\
\text { and partners' strengths. }\end{array}$ \\
\hline 4 & $\begin{array}{l}\text { Maintaining } \\
\text { relationship }\end{array}$ & $\begin{array}{l}\text { - Integrating interdependent operation and } \\
\text { maximising mutual benefits and commitment of } \\
\text { resources. } \\
\text { - Monitoring the system and process based on } \\
\text { performance and self-control internally. } \\
\text { - Long-term rewards based on each party's } \\
\text { behaviour and trust. } \\
\text { - Adjusting existing processes and strategies. } \\
\text { - Developing plans and strategies for continual } \\
\text { relationship. }\end{array}$ \\
\hline 5 & $\begin{array}{l}\text { Terminating } \\
\text { relationship }\end{array}$ & $\begin{array}{l}\text { - Making decision on termination based on the } \\
\text { extent of mutual interest and performance (cost, } \\
\text { profit, technology transfer, etc.) analysis of } \\
\text { continuing the inter-firm network. }\end{array}$ \\
\hline
\end{tabular}

Source: Batonda and Perry (2003) 
INTERNATIONAL JOURNAL OF ACADEMIC RESEARCH IN BUSINESS AND SOCIAL SCIENCES Vol. 10, No. 10, 2020, E-ISSN: 2222-6990 @ 2020 HRMARS

Selecting a potential network partner should be based not only on the process but also on the analysis and evaluation of those criteria. The more choices for specific networks will improve network performance. Additionally, the more formalised the partner selection process, the higher the success rate of the business network.

\section{Research Methodology}

This study was conducted using the qualitative case study method. The qualitative method was used with the case study approach for data collection, which was done through in-depth face-to-face interviews.

Qualitative case research results are more useful, and the findings would provide a better understanding of the behaviour of firms (Charmaz, 2008). From this perspective, networks contribute to the micro-level inter-company network analysis. This study has argued that a practical and inquisitive approach is needed to better understand the inter-firm network phenomenon in Malaysia.

The selection of case studies was done according to non-probability sampling, specifically, purposive sampling. Korean firms were selected based on the criteria of location, sector, and availability. The selected companies were in a region of Malaysia comprising mainly of Korean companies in the industrial and commercial sectors. The target interviewees were key decision-makers within each firm as table 2 .

Table 2 List of interview participants

\begin{tabular}{|l|l|l|}
\hline Company & Position & Code name \\
\hline Samsung Electronics (M) Sdn Bhd & Managing Director & SE1 \\
\cline { 2 - 3 } & Procurement Manager & SE2 \\
\cline { 2 - 3 } & Quality Manager & SE3 \\
\cline { 2 - 3 } & Production Manager & SE4 \\
\hline DYP Sdn Bhd & Managing Director & DY1 \\
\cline { 2 - 3 } & Production Manager & DY2 \\
\hline MSSC Sdn Bhd & Managing Director & MS1 \\
\cline { 2 - 3 } & Sales Manager & MS2 \\
\hline POSCO Malaysia Sdn Bhd & Managing Director & $\mathrm{PM} 1$ \\
\cline { 2 - 3 } & Sales Manager & $\mathrm{PM} 2$ \\
\cline { 2 - 3 } & Production Manager & $\mathrm{PM} 3$ \\
\hline JoonHee Micron Sdn Bhd & Managing Director & $\mathrm{JM} 1$ \\
\cline { 2 - 3 } & Sales Manager & $\mathrm{JM} 2$ \\
\hline YHP Sdn Bhd & Managing Director & $\mathrm{YH} 1$ \\
\hline & Sales Manager & $\mathrm{YH} 2$ \\
\hline
\end{tabular}

Furthermore, the researcher used the advantage of working in one of the Korean companies to network and gain access to other Korean companies and its suppliers around the same area and same industry. 
INTERNATIONAL JOURNAL OF ACADEMIC RESEARCH IN BUSINESS AND SOCIAL SCIENCES

Vol. 10, No. 10, 2020, E-ISSN: 2222-6990 @ 2020 HRMARS

\section{Findings}

\section{Motives for Inter-firm Network}

Based on the findings, there were three main motives for Korean firms to establish inter-firm networks with suppliers in Malaysia, i.e. (1) locational decision, (2) low-cost sourcing, and (3) easiness for procurement.

\section{Locational Decision}

The findings indicated that locational decision was one of the motives for inter-firm network. Gress and Poon (2007) have studied the locational decisions of inter-firm networks. Their findings indicated that inter-firm networks (customer and supplier) and inter-firm relationships (in the form of parental knowledge of the host country) played an important role in positioning the business. Network relationships should be considered in strategic decision making. In a recent study of Korean subsidiaries located overseas, Kwon (2010) has reported a positive relationship with market orientation, technology advantage, positive network relationships with local suppliers and customers, and overseas subsidiary performance. Korean subsidiaries with superior technology advantages and aggressive networks tend to have greater benefits in terms of ease of supply, competitive production costs, and stable quality control. A Korean subsidiary in Malaysia has indicated that a successful firm tends to maintain close ties with its parent company and have a tendency to take greater autonomy and more standardised production strategies in strategy and pricing. Besides, successful companies look for growth opportunities and are more committed to the market. The importance of locational issues in inter-firm network may differ across industries, such as assembly plant-oriented electronics or automobile industry to lead the company jointly with resources located in specific areas. Gulati \& Gargiulo (1999)'s 'locational embedded' is the company's position in the entire network. Nonetheless, it is well known in economic geography that this kind of business network can be constrained by location-based resources, which can cause the entire business network to decline.

This excerpt demonstrates that most key interviewees have considered geographical advantages particularly important for building, developing, and evolving inter-firm networks.

'Locational decision is important for business relationships, and it is for

building social networks and cooperation in the manufacturing industry

especially electronics industry.' (SE1, 2014)

Another interviewee specified the locational benefits between firms engaging in collaborative business:

'Distance is quite important factor for the development of long-term interfirm co-operation in sustainable transaction.' (MS1, 2014)

\section{Low-cost Sourcing}

Overseas sourcing in low-cost countries was one of the main motivations to establish inter-firm networks for many Korean companies as well as most other foreign companies. Many companies have felt the need to expand overseas, especially to reduce overseas production costs, particularly to the ASEAN and other big markets. As a matter of course, firms have taken their current products and competencies and tapped into foreign markets to take advantage of networks due to low cost. Through export-oriented FDI, four ASEAN countries have been able to rapidly shift to a 
INTERNATIONAL JOURNAL OF ACADEMIC RESEARCH IN BUSINESS AND SOCIAL SCIENCES Vol. 10, No. 10, 2020, E-ISSN: 2222-6990 @ 2020 HRMARS

manufacturing-based economy where economic growth can be achieved thanks to the rapid expansion of exports.

Most managers were concerned about costs, but there was also a need for concern over the uncertainty and the necessity to build long-term network strategic benefits.

'Samsung Electronics had been able to shift specific products of its manufacturing and sourcing activities to low-cost country especially ASEAN countries.' (SE1, 2013)

The cost of purchasing raw materials and components from external suppliers are very important. For example, in the electronics industry, especially home appliance products, cost of components and parts purchased from external sources may total to more than $70 \%-90 \%$ of the raw materials. This emphasises the importance of decisions concerning procurement activities. Low-cost sourcing determines the most important part of the final cost of the product (Benyoucef, et al., 2003).

\section{Easiness for Procurement}

Approximately $70 \%$ of Korean electronics companies (including electrical and electronics component) in Malaysia are dependent on Samsung Electronics. Most of these companies are in Seremban and Klang where the Samsung Electronics Complex has been around since the 1990s. Samsung Electronics' parts production and supply system consists of five layers. The first layer is made up of other subsidiaries under the Samsung group and accounts for the value of components purchased by Samsung Electronics. For instance, Malaysia Samsung Steel Centre (hereafter MSSC), as a subsidiary of Samsung Construction and Trade Corporation (hereafter Samsung C\&T), has played the role of supplying steel materials from POSCO and other steelmakers. Many subsidiaries within the Samsung Group that supply key components and make up the first layer are protected by the group. Legally, they are separate companies, however, many related subsidiaries such as electric and electronics and logistics operate as part of the same company according to Samsung's business plan. The second tier consists of multinational electronic components companies. Multinational companies have a strategic alliance with Samsung Electronics due to the size of the production process and the importance of business. Next, the third tier includes suppliers that outsource the production of parts that Samsung itself can produce but does not for reasons of cost or capacity. These companies principally supply small-sized microwave components. Samsung Electronics gets these low-priced microwave components from companies such as the Korean-owned Youngreem Electronics. On the other hand, the fourth tier consists of domestic subcontractors supplying components that Samsung Electronics cannot produce. The main companies in this layer include DY Power, which handles High Voltage Transformer (HVT) and Elentec, which produces printed circuit boards (PCBs). The final tier of the supply chain consists of small and medium component suppliers located in industrial complexes. Since Samsung Electronics is supplying low-cost parts, the price competition is intensifying. The company also imports some components from China.

'It's easy to source parts because there are many suppliers around. Internally,

logistics costs can be reduced and short lead time can be secured.' (SE2, 2014)

Supplier relationship with Samsung Electronics and price bargaining power can vary depending on which tier the supplier belongs to. 
INTERNATIONAL JOURNAL OF ACADEMIC RESEARCH IN BUSINESS AND SOCIAL SCIENCES Vol. 10, No. 10, 2020, E-ISSN: 2222-6990 @ 2020 HRMARS

\section{Selection Criteria of Suppliers in Malaysia}

A customer will identify, evaluate, and select its suppliers according to a documented procedure. The selection criteria of every company should comply with that of the supplier's requirements, including the supplier's internal condition and external relationship with other companies. Suppliers can have purchase and/or service agreements as well as any kinds of partnership in place with all its subsuppliers, service providers, and partners.

In the selection of new suppliers, priority is given to sustainable businesses to upgrade the diversity and range of products in the supply chain.

The supply selection network model of Korean MNCs emphasised seven points i.e. (1) business structure, (2) production capability, (3) partner experience, (4) quality policy, (5) price competitiveness, (6) business potential, and (7) relationship. When they failed to find the right supplier based on the determined criteria, the Korean MNCs tended to adopt an alternative strategy to find new suppliers by applying the existing criteria except for business potential.

\section{Business Structure}

Parallel to the selection criteria proposed by Dicken and Hassler (2000), the findings have indicated that business structure is one of the main criteria for choosing a supplier by Korean firms. Buyers can use the published supplier ratings to determine a supplier's financial condition and financial viability in the short- and medium-term. For example, if a supplier has recently been exposed to significant debt, there is a possibility that the supplier will be declared bankrupt before fulfilling its obligation to the buyer.

'Most supplier that do business with us are small and medium-sized companies. If financial uncertainty is large, the risks to the transaction may also increase as much greater.' (SE1, 2013)

In the procurement process, the main goal of financial evaluation is to minimise risk by analysing the supplier's financial condition and assessing credit risk using financial data and credit evaluation.

\section{Financial Status}

The buyer may refer to published supplier ratings from external credit insurance companies such as Coface, Euler Hermes or Korea Trade Insurance Corporation to determine a supplier's financial status such as financial feasibility and vulnerability in the short and long term. Domestic credit insurance provides the necessary protection by consolidating the customer base and creating larger receivables for fewer customers. If the supplier has faced significant financial difficulties, such as bad debt and non-smooth cash flow, this can be implied as a sign of caution about the possibility that the supplier might go bankrupt before executing its payment to the buyer based on the mutual contract.

\section{Payment Terms}

In a mutual contract between a buyer and supplier, the price term specifies what the suppliers are paid regardless of the actual production cost to execute its contractual condition. In the mutual contract, a payment term is specified, which determines how much the suppliers are paid. For example, under a mutual contract with a buyer, suppliers can receive a percentage of the total cost incurred or simply pay for time and materials. The various payment terms for each supplier may be imposed, depending on the supplier's requirements or the characteristics of each supplier, which may take the form of an offence. For instance, payments can only be made if the payment remains 
INTERNATIONAL JOURNAL OF ACADEMIC RESEARCH IN BUSINESS AND SOCIAL SCIENCES Vol. 10, No. 10, 2020, E-ISSN: 2222-6990 @ 2020 HRMARS

within the specified target inventory service level within a certain period from the date of delivery, such as 15 days, 30 days, 45 days, 60 days or longer.

\section{Non-payment Terms}

Contracts can specify all kinds of details relating to how the contract is executed, such as contract quantity, delivery frequency, delivery location, service level, quality level, technical specifications, the period of contract, and so on.

Prior to selecting a partner, the location of the supplier, the physical distance, and the cost analysis should be done. The closer the physical distance is, the more opportunities for information sharing and exchange, and the easier it is to develop long-term transactions. In the long-term, buyers who want continuous trading will prefer a company located close by.

Suppliers tend to place production facilities in the same city as their customers since the cost of establishing even a relatively small-scale plant near the electronics and car manufacturing companies can be reduced by lowering the transportation costs. Parts makers located close to the electronics company (the final customer) have more chances to get orders as shown table 3

Table 3 Physical distance with the main partner

\begin{tabular}{|c|c|c|c|c|}
\hline & \multirow[t]{2}{*}{ Company } & \multicolumn{3}{|l|}{ Distance } \\
\hline & & $\begin{array}{ll}\text { From } & \text { Korean } \\
\text { suppliers } & \end{array}$ & From local suppliers & To the main customer \\
\hline 1 & $\begin{array}{l}\text { Samsung } \\
\text { Electronics }\end{array}$ & Below 20 km & Below 50 km & Exported \\
\hline 2 & Joonhee & $20 \mathrm{~km}$ & $70 \mathrm{~km}$ & $14 \mathrm{~km}$ \\
\hline 3 & MSSC & $27 \mathrm{~km}$ & Imported & $8 \mathrm{~km}$ \\
\hline 4 & DPC & $1 \mathrm{~km}$ & $20 \mathrm{~km}$ & $9 \mathrm{~km}$ \\
\hline 5 & YHP & $19 \mathrm{~km}$ & $32 \mathrm{~km}$ & $13 \mathrm{~km}$ \\
\hline 6 & $\begin{array}{l}\text { POSCO } \\
\text { Malaysia }\end{array}$ & Imported & Imported & $21 \mathrm{~km}$ \\
\hline
\end{tabular}

Based on Table 3, electrics and electronics parts, especially small items, can be delivered to the nearby final assembler before reaching their destinations. The case of imported items and PCB was the rule and the case of seats was a rare exception. Furthermore, the average distance from the supplier to the final assembler for electronics parts was calculated, and among them, 57 items travelled longer distances than imported items. Table 4.2 shows the average distance from the suppliers to the main customer. Their affiliated parts suppliers were located around them, with the distance generally below $100 \mathrm{~km}$, except for certain parts. This must be due to the fact that (1) the cost competitiveness of the suppliers were realised by enjoying lower logistics costs, just in time delivery system, and information sharing, which were more important than the economies of scale in many cases and (2) many Korean suppliers in Malaysia did not have sufficient production volumes to supply to local customers and other foreign customers. This was also a reflection of the mixed sourcing strategy adopted by those Korean electronics companies. 
INTERNATIONAL JOURNAL OF ACADEMIC RESEARCH IN BUSINESS AND SOCIAL SCIENCES Vol. 10, No. 10, 2020, E-ISSN: 2222-6990 @ 2020 HRMARS

\section{Production Capacity}

The capacity of a supplier to increase the production and delivery volume within a short delivery time is important because the buyer cannot be certain of the exact quantity requirement during the contract period. This is especially true for 24-hour operating companies such as Samsung Electronics, which emphasises on production capacities and delivery availabilities. Surge capacity is available when a supplier has access to second or third shifts, overtime, underutilised facilities, etc.

'Our plant produces only microwave ovens, which sell not only to the Malaysian market but to the whole world. The production capacity is an average of 700,000 units a month and operates the plant 24 hours a day and night. So, when selecting a supplier, we select a supplier that can cover the production capacity of our plant.' (SE4, 2013)

To determine the capabilities of a supplier, a buyer can take several actions. Firstly, they can request the product and test it to make sure it meets their requirements. Secondly, they can visit the supplier's production facilities and management personnel (quality and production managers) to ensure that all the staff there are responsible for the critical functions of the product. For instance, a buyer seeking to purchase raw materials such as electronics components from a supplier may be trained to ensure they understand each aspect of the product itself, technical specification, and quality requirement. Thirdly, the buyer can request the supplier to produce the product in small quantities to supply the service components for irregular orders from the buyer. As part of supplier requirements to the sub-contractor, a supplier shall also consider environmental protection, occupational health and safety management at work for its second-tier and third-tier suppliers, including the waste handling/recycling sub-contractor. Hence, the buyer needs to evaluate the supplier and its sub-suppliers' performance and set improvement targets and monitor their practical implementation. These requirements shall be aligned with the supplier's requirements.

\section{Partner Experience}

The partner experience includes intimacy among the partners created during the previous partnership, which can have a significant impact on the inter-company network (Dekker, 2008). In particular, past experience is critical in relationships with suppliers that have entered the overseas market. Samsung Electronics emphasised the experience of its partners in developing and maintaining networks. Partners formulate their experiences through lessons learned from past relationships and continue to share many of their information with related partners, including information sharing and performance measurement and monitoring.

'There is a great advantage when new or existing companies have experience with large company. For example, stable supply is possible because it is stabilised in many areas such as quality control and production process control.' (SE3, 2014)

The partner experience is important in inter-firm relationships where business interdependencies are strong. This experience enhances the strength and scalability of inter-firm networks.

\section{Quality Policy}

The objective of quality policy is to establish and maintain a documented quality system, which ensures that the products and process conform to specified requirements. Before qualifying as a new supplier, the certification supervising department evaluates the engineering capability, product 
INTERNATIONAL JOURNAL OF ACADEMIC RESEARCH IN BUSINESS AND SOCIAL SCIENCES Vol. 10, No. 10, 2020, E-ISSN: 2222-6990 @ 2020 HRMARS

stability, and R\&D capability of the supplier by reviewing the documents and may request the necessary supplementary materials from the supplier.

'All employees are committed to the concept of "No Spec, No Work" and performing all applicable quality improvement activities on a continuous basis.' (SE3, 2014).

The quality policy for minimisation of defective products starts with receiving quality claims, analysing them, devising countermeasures to taking corrective actions by exactly identifying customer dissatisfaction with the products and thus effectively handling claims and preventing the recurrence of the same problem, thereby, securing good product quality and credibility.

'To qualify as a new supplier of Samsung, the certification supervising department evaluates the engineering capability, product stability, and R\&D capability by reviewing the documents and may request the necessary supplementary materials from the supplier. Samsung quality audit is carried out based on the vendor quality audit procedures.' (SE3, 2014).

One of the respondents gave an additional explanation regarding quality:

'If the customer requires a high-quality level, the supplier can make efforts to improve the quality on its own. In the future, quality competitiveness of small and medium-sized companies, which are suppliers, can be improved as well.' (DY2, 2014).

\section{Price Competitiveness}

Price competitiveness in manufacturing depends on whether suppliers are sustainably producing high-quality products at a low cost. The most common costs involved in producing a product are raw material purchase price, production cost, transportation cost, and labour cost. These production and operating costs are taken into consideration when selecting suppliers. Operating costs include transaction processing. A partner company that can supply low-cost raw materials and is located nearby can reduce the cost of raw materials' purchase and logistics. It is also the same for labour costs. Cost is, therefore, a very important criterion for selecting the right supplier.

'One of the reasons why Samsung Electronics invested in Malaysia is its cheap labour costs. While there are cheap workers directly employed by Samsung Electronics, suppliers can lower costs through lower labour costs.' (SE1, 2013).

The current trend of inter-firm relationships is evolving into more collaborative forms based on cooperation and mutual benefit in the form of price-based competition.

'In the beginning, our company produced in Korea and exported it to Malaysia, but it recorded a loss due to rising materials and labour costs. Since then, it has invested directly in Malaysia and established a production line and has been selling it stably until now. The price required by the final buyer can be met to a certain extent, and the company is also enjoying low-cost benefits.' (DY1, 2014).

A company always aims to achieve the minimum price of the product to increase profitability. Therefore, companies must find low-cost supply bases that can minimise manufacturing costs associated with the production of their products. 
INTERNATIONAL JOURNAL OF ACADEMIC RESEARCH IN BUSINESS AND SOCIAL SCIENCES Vol. 10, No. 10, 2020, E-ISSN: 2222-6990 @ 2020 HRMARS

\section{Business Potential}

Most of the large Korean companies preferred long-term transaction for a stable supply from their partners because they would not stop with just a single transaction. Therefore, in the early days, MNCs have tended to focus on the transaction possibility rather than profitability. Additionally, MNCs usually check the suppliers who desire to do business them.

'Most companies, especially manufacturing, want deals such as sustainable supply rather than one-off deals. The sustainability of the transaction is not possible with one side's efforts and is determined by the efforts of both companies.' (PM1, 2015)

'If the potential supplier has quality and price competitiveness and is willing to continue to do business with us, we are willing to do more transaction volume and long-term business.' (SE1, 2015).

Nevertheless, some respondents had different opinions.

'For POSCO and Samsung, it is important to have a deal with suppliers because they have to buy the same product reliably for a long period of time. Like us, from a small- and medium-sized company's perspective, business potential is not such an important part of selecting a company. The biggest reason is frequent model changes, and many one-off transactions occur. It is difficult to make it officially to consider as selection criteria every time.' (YH1, 2015)

'If the size of our company grows in the future and we can purchase various parts in the long term, business potential as criteria can be considered, but it is now a very meaningless criteria.' (JM1, 2015)

\section{Relationship}

The ease of communication and negotiation with the supplier determines the long-term relationship between the supplier and the manufacturer. Language, business conventions, ethics, and preferred communication methods vary from country to country. In the past, the tendency was favoured by companies from the same country. Particularly, companies from East Asian countries such as Japan and Korea showed such a tendency when they entered the overseas market and seem to be continuing to some extent to date.

This study found that suppliers of the same nationality as the electronics companies had better chances of getting its business. Most Korean companies had a relatively large number of Koreans. This suggests that there is an intimate relationship between Korean electronics companies and Korean component makers in Malaysia or other raw material suppliers.

'If the owner of the supplier is the same nationality or Korean company, there will not be many communication problems between both sides, especially since it can be contacted directly from the headquarters, so there will be no communication problems. It can also share a lot of information, which helps with long-term business.' (SE2, 2015)

The effectiveness of sourcing strategies is also important. Although many Korean manufacturers tend to transplant confidential relations with their Korean suppliers in Malaysia, European and American companies tend to use existing parts suppliers in Malaysia, regardless of nationality. The familiar and 
INTERNATIONAL JOURNAL OF ACADEMIC RESEARCH IN BUSINESS AND SOCIAL SCIENCES Vol. 10, No. 10, 2020, E-ISSN: 2222-6990 @ 2020 HRMARS

close-knit buyer-supplier relationship in Korea did not seem to change significantly after Korean manufacturers have established plants in Malaysia.

Gong (2003) has supported the view that the parent company's culture will be transferred to its overseas subsidiaries. When examining organisational culture as a control mechanism, the foreign subsidiaries are shown to be managed according to their parent's culture. In the past, Korean and Japanese companies had shown a similar relationship between the parent company and foreign subsidiaries. Relationship with the parent company has required the foreign subsidiary to depend on the management of the parent company, which has made it difficult for the subsidiary to localise its personnel (Gong, 2003). The reliance of the Korean manager or those in higher positions made it difficult to localise the subsidiaries overseas due to communication problem, whereby Koreans are not willing to learn the local language, and the lack of shared understanding. The management in Korean companies has entrusted its subordinates with decision making, so that they may apply a similar management style to its subsidiary overseas. The number of expatriates in overseas subsidiaries reflects the extent of control by MNCs in influencing its overseas subsidiaries (Konopaske et al., 2002). The spread of the local business culture is limited due to the lack of understanding of the local culture and the strong intention by the parent company, which propagates from the home country's business style or culture to the host country. Cultural control can be achieved by the parent company by placing an expatriate in the subsidiary who can directly manage the operation of the subsidiary while working in a regional headquarters.

The prevalence of inter-firm networks in Korea can be attributed to the culture of Korea. Their high context culture means that the shared code of communication, the ability to use speaking contracts, and a profound culture are well suited to work most effectively in these inter-firm networks through long-standing relationships with individuals. These inter-company networks are a strong feature of Korean culture and depend on mutual trust. Their collectivist culture means that they work more effectively when working together, not individually.

Collectivism deeply pervades cultures in Northeast Asia, which are influenced by the Confucian society. Collectivist cultures such as in China, Korea, and Japan, which have a strong Confucian influence, emphasise the goals of families and workgroups rather than individual needs or desires. Although the Korean culture has quite a collectivistic tendency, many people there tend to be fast in adopting a more individualistic culture due to being influenced by an increasingly westernised and individualised economic and social culture (Cho, 2010). Therefore, it is possible to attribute the prevalence of inter-firm networks as due to their collectivist values, high context power distance, and their ability to function using mutual trust. Inter-company networks are widespread as they grow and evolve in the Korean culture. Furthermore, Koreans tend to build trustable and personal relationships with their business partners. As part of developing this social relationship, Koreans spend more time on business socialisation. In this sense, Koreans regard social interaction as important.

'Usually, companies with Korean nationality have the same culture, so ties are stronger than suppliers of other nationalities. Reasons vary. Korea, which foreigners know well, has a culture of "hurry up". This culture applies to business, and since the relationship that suppliers can support whenever customers want, other foreign companies cannot easily accept it.' (SE1, 2015) 'Korean companies abroad have strong ties between them, giving a glimpse into a collective culture. So, it is not easy for companies of different nationalities or other cultures to enter.' (JM1, 2015) 
INTERNATIONAL JOURNAL OF ACADEMIC RESEARCH IN BUSINESS AND SOCIAL SCIENCES Vol. 10, No. 10, 2020, E-ISSN: 2222-6990 @ 2020 HRMARS

\section{Conclusion}

The findings revealed that there were three main motives for Korean firms to establish inter-firm networks with suppliers in Malaysia, which are locational decisions, low-cost sourcing, and easiness for procurement. In addition, the Korean firms tended to place some priority on selecting suppliers. Particularly, through the financial position of the new supplier, the company would check its financial solvency and stability and verify that it has sufficient production capacity. From a quality policy perspective, the emphasis was on formalised quality specification. The most notable feature was that most of the Korean subsidiaries favoured businesses from the same nation from a stable perspective of transaction, and they also made choices with a focus on potential transaction possibilities for longterm supply.

In addition, the availability of quality control by the new supplier also served as a priority for Korean firms in selecting the suppliers. The reputation of new and existing suppliers was also identified as an important factor in maintaining the relationship. Korean firms also sought alternatives when transactions with existing suppliers were suspended or contracts were terminated, by applying criteria such as business structure, production capacity, quality policy, relationship, and price competitiveness to develop new suppliers. This study sheds light on the behaviour of Korean firms in host countries and the criteria are useful findings for local and international suppliers to understand when they are approaching Korean firms in their future business dealings.

\section{References}

Barney, J. B. (2001), Is the resources-based "View" A useful perspective for strategic management research? Academy of Management Review, Vol.26, No.1, 41-56

Bass, L., Klein, M., Bachmann, F. (2003). Quality Attribute Design Primitives and the Attribute Driven Design Method. In: 4th International Workshop on Product Family Engineering, Bilbao, Spain, October 3-5 (2003)

Batonda, G., \& Perry, C. (2003). Approaches to relationship development processes in inter-firm networks, European Journal of Marketing, 37(10), 1457 - 1484.

Benyoucef, L., Ding, H., \& Xie, X. (2003). Supplier Selection Problem: Selection Criteria and Methods, Institut National De Recherche En Informatique Et Automatique

Charmaz, K. (2006). Constructing grounded theory: A practical guide through qualitative analysis. London: $S A G E$

Chin, K-S., Chan, B. L., and Lam, P-K. (2008), Identifying and prioritizing critical success factors for competition strategy, Industrial Management \& Data Systems, Vol. 108 No. 4 437-454.

Crone, M., \& Watts, H. D. (2003). The Determinants of Regional Sourcing by Multinational Manufacturing Firms: Evidence from Yorkshire and Humberside, UK, European Planning Studies, 11(6), $717-737$.

Das, T. K., and Teng, B-S. (2000), Instabilities of Strategic Alliances: An internal tensions perspective, Organization Science, Vol.11 No. 1, 77-101.

Dekker, H. C. (2008) Partner selection and governance design in interfirm relationships," Accounting, Organizations and Society, Vol. 33(7-8), pages 915-941.

Dicken, P., \& Thrift, N. (1992). The organization of production and the production of organization: why business enterprises matter in the study of geographical industrialization, Transactions of the Institute of British Geographers, NS 17, pp. 279-291 
INTERNATIONAL JOURNAL OF ACADEMIC RESEARCH IN BUSINESS AND SOCIAL SCIENCES Vol. 10, No. 10, 2020, E-ISSN: 2222-6990 @ 2020 HRMARS

Dicken, P. (1998), Global Shift: Transforming the world economy. New York: Guilford Press

Dicken, P., and Hassler, M. (2000), Organizing the Indonesia Clothing Industry in the Global economy: the role of business networks, Environment and planning A 32, 263-80.

Gong, Y. (2003), Subsidiary Staffing in International Enterprises: Agency, Resources, and Performance. Academy of Management Journal, 46:728-739.

Gress, D. R., \& Poon, J. P. H. (2007), Firm networks and Korean subsidiaries in the United States. Growth and Change, 8(3), 396-418.

Gulati, R. (1995), Social Structure and Alliance Formation Pattern: A longitudinal Analysis, Administrative Science Quarterly, 40; 619-642.

Gulati, R. (1998), Alliances and Network, Strategic Management Journal 19, 293-317.

Gulati, R., and Gargiulo, M. (1999), Where Do Network Forms Come From?, American Journal of Sociology, March, 177-231.

Gulati, R. (2007). Managing Network Resource: Alliance, Affiliations, and Other Relational Assets, Oxford University Press: New York.

Hoskisson, R. E., Eden, L., Lau, C. M., and Wright, M. (2000), Strategy in emerging economies. Academy of Management Journal, 43, 249-67

Johanson, J., \& Mattsson, L-G. (1987), Interorganizational Relations in Industrial Systems: A Network Approach Compared with the Transaction-Cost Approach, International Studies of Management \& Organization, Vol. 17

Johanson, M., and Kao, P. T. (2010). Networks in internationalisation, Pla-Barber, J. and Alegre, J. (Ed.) Reshaping the Boundaries of the Firm in an Era of Global Interdependence (Progress in International Business Research, Vol. 5), Emerald Group Publishing Limited, Bingley, pp. 119142.

Konopaske, R., Werner, S., \& Neupertm, K. E. (2002), Entry Mode Strategy and Performance: The Role of FDI staffing, Journal of Business Research, 55:759-770.

Kraaijenbrink, J., Spender, J-C., \& Groen, A. J. (2010), The Resource-based View: A review and Assessment of Its Critiques, Journal of Management, Vol. 36 No. 1, 349-372

Krätke, S., \& Borst, R. (2007). EU Eastern Enlargement and the Configuration of German-Polish Inter-Firm Linkages, Tijdschrift voor Economische en Sociale Geografie, 98(5), 621-640.

Kwon, Y. C. (2010). Market orientation of Korean MNC subsidiaries and their performance in the Chinese and Indian markets. International marketing Review, 27(2), 179-199.

Lavie, D. (2006), The competitive advantage of interconnected firms: An extension of the resourcesbased view, Academy of Management Review, 31:638-658

Lee, C. Y. (2004), A comparative study of Automobile Industry Between Japan and Korea, Asia Academy of Management, Fourth Conference.

Li, R., \& Cheong, K-C. (2017). Huawei and ZTE in Malaysia: The Localisation of Chinese Transnational Enterprises, Journal of Contemporary Asia, 47(5), 752-773.

$\mathrm{Li}, \mathrm{X} .$, \& Yeung, Y. (1999). Inter-firm linkages and regional impact of transnational corporations: company case studies from Shanghai, China, Geografiska Annaler, 81 B (2), 61-72.

Lopez-Aymes, J-F., and Salas-Porras, A. (2008), Assessing Nationalistic Expressions of Korean companies: Korean FDI in Mexico, UCLA Center for Korean Studies.

Lu, J. W. (2002). Intra- and Inter-organizational Imitative Behavior: Institutional Influences on Japanese Firms' Entry Mode Choice. Journal of International Business Studies, 33(1): 19-37. 
INTERNATIONAL JOURNAL OF ACADEMIC RESEARCH IN BUSINESS AND SOCIAL SCIENCES Vol. 10 , No. 10, 2020, E-ISSN: 2222-6990 @ 2020 HRMARS

Ma, X. (2006), Relationship between Exporters and their Foreign Sales and Marketing Intermediaries, Advances in International Marketing, Volume 16, 23-48

Moeller, K. (2010), Partner selection, partner behavior, and business network performance, An empirical study on German business networks, Journal of Accounting Organizational Change, Vol. 6 No.1, 27-51.

Park, S. O., \& Nahm, K-B. (1998). Spatial structure and inter-firm networks of technical and information producer services in Seoul, Korea, Asia Pacific Viewpoint, 39(2), 209-219.

Rooks, G., Raub, W., Selten, R., and Tazelaar, F. (2000). How Inter-firm Co-operation Depends on Social Embeddedness: A Vignette Study, Acta Sociologica, 43, 123-137.

Shah, R. H., \& Swaminathan, V. (2008). Factors influencing partner selection in strategic alliances: the moderating role of alliance context, Strategic Management Journal, 29(5), 471-494.

Son, J. W., Han, S. H., Rojas, E. M. (2015). Embeddedness and Collaborative Venture Networks Among Korean Construction Firms for Overseas Construction Projects, Journal of Civil Engineering and Management, 21(4), 478-491.

Su, F., Khan, Z., Lew, Y. K., Park, B. I., \& Choksy, U. S. (2020). Internationalization of Chinese SMEs: the role of networks and global value chains, Business Research Quarterly, 23(2), 141-158.

Walker, D., \& Hampson, K. (2003) Procurement strategies: a relationship-based approach. WileyBlackwell, Hoboken.

Yang, Q., Wang, Y., \& Jiang, C. (2019). Local Relational Embeddedness and Subsidiaries' Innovative Performance, Journal of Behavioral \& Applied Management, 20(1), 17-35.

Yozi, J. (1997), Computer Networks and Inter-firm Relationship in the Automobile Industry: A Comparative Study of Japan and Korea. Computers Industry Engineering, Vol.33, No.3-4, 635638.

Zheng, Y., Liu, J., \& George, G. (2010). The Dynamic Impact of Innovative Capability and Inter-firm Network on Firm Valuation: A Longitudinal Study of Biotechnology Start-ups. Journal of Business Venturing, 25(6) 593-609. 